\title{
Property tax and fiscal discipline in OECD countries *
}

\author{
Andrea F. Presbitero \\ International Monetary Fund \\ apresbitero@imf.org

\section{Agnese Sacchi} \\ Universitas Mercatorum \\ a.sacchi@unimercatorum.it
}

\author{
Alberto Zazzaro \\ Università Politecnica delle Marche \\ a.zazzaro@univpm.it
}

January 14, 2014

\begin{abstract}
This paper investigates the effects of the property tax on national fiscal discipline in a sample of OECD countries over the period 1985-2006. Our results show that a larger share of property taxes in total tax revenues is associated with a smaller primary deficit-to-GDP ratio. Moreover, a greater reliance on property taxation at a sub-national level contributes to straighten fiscal discipline, regardless of the degree of tax decentralization in a country. Our results suggest that institutional reforms towards fiscal decentralization should be mostly focused on the design of the local tax structure in order to promote country's fiscal sustainability.
\end{abstract}

JEL Classification: H62, $H^{7} 1, H^{77}$, E62

Key words: Property taxation, Tax decentralization, Sub-national governments, Fiscal balance.

\footnotetext{
*Agnese Sacchi (corresponding author), Faculty of Economics - Universitas Mercatorum (Rome, Italy). Email: a.sacchi@unimercatorum.it. This working paper should not be reported as representing the views of the IMF. The views expressed in this working paper are those of the authors and do not necessarily represent those of the IMF and IMF policy. Preliminary draft. Do not quote without authors' permission.
} 


\section{Introduction}

Large and increasing public debts in industrialized economies and the sovereign debt crisis in the euro area are urging policy makers and economists to envisage efficient mechanisms and rules to improve government fiscal balances. As a result, there is a growing interest about which are the most efficient tax instruments that governments can use to consolidate their fiscal position. In this perspective, the adoption of a property tax, especially on land and other immovable properties, is a widely debated issue not only in the political and media arena (The Economist, 2013a,b), but also among scholars and international organizations (OECD, 2012; Norregaard, 2013).

In spite of this interest and the attention paid by the literature to vices and virtues of property taxes for different macroeconomic and fiscal outcomes, the impact of the use of property taxation on overall fiscal balance is still an unexplored issue. ${ }^{1}$ Against this backdrop, in this paper we investigate the effect of property taxes on national fiscal discipline in a sample of 19 OECD countries over the period 1985-2006 (extended to 23 countries and to a longer period, 1972-2006, in the robustness section).

The correlation between property tax and fiscal discipline is not clear-cut. On the one hand, a strong use of property taxation may improve the fiscal balance through a number of channels. First, a shift from income to property taxes could improve tax revenue collection and the country's aggregate economic performance. By burdening accumulated wealth, property taxes have less distortionary effects on the allocation of resources than income and consumption taxes (Norregaard, 2013). To the extent that property taxes are capitalized in property prices, saving, investment and labor decisions are unaltered as rates of return on real and financial assets are unaffected. In addition, as the fiscal burden of property taxes is to a certain degree independent from the use of the property, taxpayers are incentivized to employ their properties efficiently.

Second, property taxes are a more 'stable' and 'predictable' source of revenues than other forms of taxation. The property tax base is mostly immovable and taxpayers can hardly relocate to areas with lower tax rates. Further, to the extent that tax evaders invest the proceeds of their evasion in land, real estates and other immovable properties, property taxation allows to retrieve resources otherwise escaped to tax authorities. Finally, the legally defined value of properties is less volatile than income and consumption tax bases, thus reducing the cyclicality of fiscal revenues (Doerner and Ihlanfeldt, 2011; Lutz et al., 2011).

\footnotetext{
${ }^{1}$ A related literature has looked at the effect of property tax on wealth accumulation (Holtz-Eakin and Marples, 2001; Joulfaian, 2006), tax avoidance (Kopczuk and Slemrod, 2001), public goods supply (Borge and Rattso, 2008; Fiva and Ronning, 2008), local governments size (Crowley and Sobel, 2011; Liberati and Sacchi, 2013) and economic growth (Arnold et al., 2011; Acosta-Ormaechea and Yoo, 2012)
} 
Third, property taxes may discipline non-benevolent politicians. This effect reduces the wastage of resources and minimizes public expenditures. Revenue-maximizing politicians may have incentives to deliver public goods at a lower cost, as they anticipate that property values - and the revenues from property taxes - reflect the quality and amount of public goods locally available (Glaeser, 1996; Hoxby, 1999; Weingast, 2009). In addition, the high degree of salience of property taxes makes the vote of tax payers more sensitive to changes in the property tax rates (Cabral and Hoxby, 2012).

On the other hand, an increase in property taxation might worsen the fiscal balance. Levies on property, especially on inheritances and gifts, discourage individuals from wealth accumulation, reducing the propensity to save and invest (Kopczuk and Slemrod, 2001). Non-recurrent taxes on property transfers can reduce the number of market transactions and increase market price volatility. Further, the salience of property taxes raises the incentive to tax avoidance and evasion (Kopczuk, 2010). Finally, an accurate assessment of property tax bases is problematic and costly: systems of land rents are usually not updated and the legal value of properties tend to diverge from market prices, thus introducing significant disparities among areas, type and age of properties.

To assess the value of these competing hypotheses we test whether the degree of reliance on property taxes is significantly correlated with the degree of fiscal discipline at the country level. As a first step, we estimate a model in which the ratio of primary balance over GDP is function of the share of property taxes to total tax revenues (and a set of other explanatory variables).

However, the relationship between property taxes and fiscal discipline could be spurious, as the effect of property taxation may capture the effect of tax decentralization on the fiscal balance. In fact, the property tax is predominantly a local tax. Typically, it is assigned on a tax separation scheme to lower levels of government, which make unique use of such a tax base. Both traditional and public choice theories of fiscal federalism predict that the degree of tax decentralization has either "laxness" or "discipline" effects on national public deficits. ${ }^{2}$ In order to address this concern, we estimate a second model in which we measure property taxes as a share of local tax revenues and we control for tax decentralization, measured by the ratio

\footnotetext{
${ }^{2}$ The "laxness effect" of fiscal decentralization may be due to soft-budget constraints, common pool problems, and coordination failures among local and with central governments (Ter-Minassian, 1997; Wibbels, 2000; Rodriguez-Pose and Gill, 2003); the "discipline effect" may be due to vertical and horizontal fiscal competition across local governments, and transparency of tax burden and public good delivery (Brennan and Buchanan, 1980). Both effects find support in the empirical literature. de Mello (2000) finds that the degree of tax autonomy of sub-national governments causes intergovernmental coordination failures, increasing public deficit at the central and local government levels. Similarly, Baskaran (2012) documents that tax decentralization leads to higher fiscal imbalances when sub-national governments rely more on shared taxes. By contrast, Neyapti (2010) finds that revenue decentralization generally reduces budget deficits. Finally, Thornton (2009) shows that revenue decentralization has a discipline effect on the consolidated national fiscal balance, even if this effect reverts when local revenues include exclusively taxes over which sub-national governments have full autonomy.
} 
between local and total tax revenue. ${ }^{3}$

Our results can be summarized as follows: (i) a greater reliance on property taxes is associated with smaller budget deficits; and (ii) the use of property taxes at a sub-national level contributes to straighten fiscal discipline, regardless of the degree of tax decentralization. From a policy perspective, our findings lend support to the beneficial macroeconomic effects of property taxation and suggest that institutional reforms in favor of tax decentralization should focus more on the design of the local tax structure than on the degree of decentralization per se.

The plan of the paper is as follows. In Section 2 we describe trends of property taxation and local tax structures in the OECD countries belonging to our sample. In Section 3 we present the empirical strategy and in Section 4 we discuss the regression results. Section 5 concludes.

\section{Local tax structures and property tax in OECD countries}

A general trend seems that governments tend to decentralize revenue collection less than expenditure execution (Dziobek et al., 2011). Central governments mostly retain control on the collection of taxes and mandatory social contributions consistently with the prescriptions of fiscal federalism theory recommending that decentralization of taxation is only desirable for a limited share of total revenues, namely property taxes and user fees.

As for the taxing power of local governments in OECD countries, ${ }^{4}$ some stylised facts are provided by a recent study of OECD (2013): i) tax autonomy varies widely across countries (most sub-national governments have considerable discretion over their own taxes); ii) in some countries (e.g., Norway) sub-national governments have the right to vary tax rates but they actually do not use this taxing power; iii) tax sharing arrangements account for a large part of sub-national tax revenue in some federal countries as well as in many unitary countries, ${ }^{5}$ allowing local governments for less or no power to set tax rates or tax bases with respect to the case of more autonomous taxes.

Consistently with the scope of our paper, an important issue at stake is the local tax com-

\footnotetext{
${ }^{3}$ In this way, our paper also contribute to literature on tax decentralization and fiscal imbalance (see footnote 2) by controlling for the heterogeneous effects of different local taxes.

${ }^{4}$ When we talk about 'local' governments, we refer to all tiers of hierarchical institutions differing from the central/federal government in the countries of our sample (e.g., state, province, region, municipality, lander, canton, county, and so on). Even though a further horizontal disaggregation would be more precise, it would also pose several cross-country comparability problems that we want to avoid at this stage of the analysis. Moreover, decentralization data from many sources (e.g., IMF, OECD, World Bank), also those here used, do not allow any distinction among all lower tiers of government in each country and all sub-national units are usually aggregated into a single group in many empirical studies.

${ }^{5}$ As proved by Blochliger and Petzold (2009) it is sometimes difficult to distinguish whether an arrangement is tax sharing or intergovernmental transfer. The former has become, indeed, a means to provide fiscal resources to sub-national governments while maintaining central control over fiscal aggregates. In addition, tax sharing arrangements often contain an element of horizontal fiscal equalisation.
} 
position. The observation of revenue systems in OECD countries reveals that the local tax structure may have different characteristics concerning the mix of the three main taxes available to sub-national governments: those on income, consumption, and property. A different tax-mix also implies a different degree of tax autonomy not only across countries but also across tax category, leading to potential different sub-national governments' behaviours and overall budgetary outcomes. For both statistical and economic reasons, a careful distinction among different tax revenue allocation is therefore necessary.

Major local taxes such as those on personal and corporate income are mostly covered by tax sharing arrangements; their high yield makes them attractive for sub-national governments and the pooling tackles potential drawbacks of local taxation (such as mobility of the tax base). On the other hand, a sub-national governments' unique control over these revenues is basically restricted. Likewise, taxes on goods and services are even more embedded in tax sharing arrangements than income taxes; this then provides a relatively small part of the tax revenues under the full control of lower tiers of governments.

Property taxes are, instead, usually assigned with more autonomy than others to subnational governments as they are hardly involved in pure tax sharing formulas and they are basically associated with tax separation schemes (to our knowledge, the exception occurs only in Austria). This implies that even though the property tax may be applied on the basis of a national legislation, the action of local governments on such item can be more visible and accountable for citizens. Indeed, the degree of discretion given to sub-national governments to manipulate the property tax may vary but the thinking that this tax belongs to local governments is well entrenched (e.g., Martinez-Vazquez, 2008). This feature appears to be consistent over time and across countries. This would imply that among the three groups of taxes here discussed, property taxes should be the most effective to control local spending, as they are contemporaneously characterized by a large degree of autonomy and a predominance of tax separation schemes.

Differences across countries basically concern the definition of its tax base: typically, the immovable property tax base included both land and improvements (e.g., buildings); although there are some countries that only tax land (e.g., Australia). Many taxing jurisdictions also include machinery and equipment in their tax base (e.g., the United Stated and Canada). All in all, regardless of the actual tax base chosen, countries typically define that tax base coverage as broadly as possible to ensure the capture of adequate revenue in an efficient and equitable manner. 
Looking at our sample, property taxes ${ }^{6}$ represent, on average, about $2.6 \%$ of general government revenue during the years 1985-2006. Countries with higher shares are federal ones (e.g., Canada, 7.7\%, United States 7.5 and Australia 6.4\%), followed by France and Portugal presenting values higher than $4 \%{ }^{7}$

Even though the property tax does not seem to be the hearth of the overall revenue systems, it frequently contributes significantly to the financing of local governments being predominantly assigned to lower levels of government; this is especially true for the immovable tax component whose collection accrues solely to local governments in the majority of advanced economies as the countries of our sample. Hence, it is more important to consider the weight of property taxes in relation to the local tax structure.

On average, the share of property taxes over local tax revenues is about $19.3 \%$ over the period 1985-2006. Property taxation still represents the main source of the sub-national government financing in some federal countries (e.g., Australia, United States, and Belgium from 1993) as well as in some unitary ones (e.g., France and Netherlands). On the other hand, property tax is absent in Finland and Sweden as the predominant sub-national tax source in such countries is the income tax. This preference probably arises for its greater adherence to the ability-to-pay principle of taxation, and for its more effective role in reducing income inequalities, an issue particularly important in the tax/benefit structure of Scandinavian countries. This feature marks a difference with most English-speaking countries, where property taxes account for the overwhelming part of local tax revenues.

Overall, this picture provides evidence of a certain variability in the use of property tax across countries. The box plot reported in Figure 1 (panel a) confirms that the distribution of the share of property tax over total tax revenue shows a significant degree of variability across countries. While its distribution across countries is highly dispersed up to the end of the 1990s, over the last decade observations are more concentrated around the median. The share of property tax over total tax revenue exhibits also a certain level of variability over time: on average property taxes increased at the beginning of the 1990s, reaching $4 \%$ of total tax revenue in 1994, then started declining - they ware halved to $2 \%$ by 1999 - and reached $1.3 \%$ of total

\footnotetext{
${ }^{6}$ Consistently with the standard international tax classifications (i.e. from IMF and OECD), our data refer to total property tax revenue, which means the sum of: recurrent taxes on immovable property; recurrent taxes on net wealth; estates, inheritances and gifts taxes; financial and capital transaction taxes; other recurrent or nonrecurrent taxes on property. However, a finer partition is not allowed and only the aggregate value is captured by our data. In any case, we know that within this aggregate recurrent taxes on immovable property constitute by far the largest sub-component in OECD countries, presenting also a broadly stable revenue ratio; while, net wealth and inheritance and gift taxes have been scaled-back or eliminated in some countries (e.g., UK and US have no net wealth taxation). For further details see Norregaard (2013).

${ }^{7}$ The countries included in the analysis are: Australia, Austria, Belgium, Canada, Denmark, Finland, France, Germany, Greece, Iceland, Italy, Netherlands, Norway, Portugal, Spain, Sweden, Switzerland, United Kingdom, and United States.
} 
Figure 1: Property tax and primary balance across OECD countries: 1985-2006

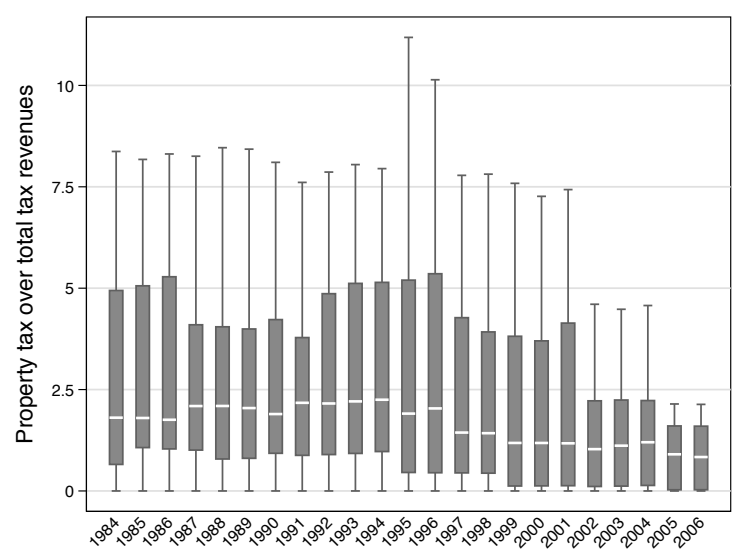

(a) Property tax (\% total tax revenue)

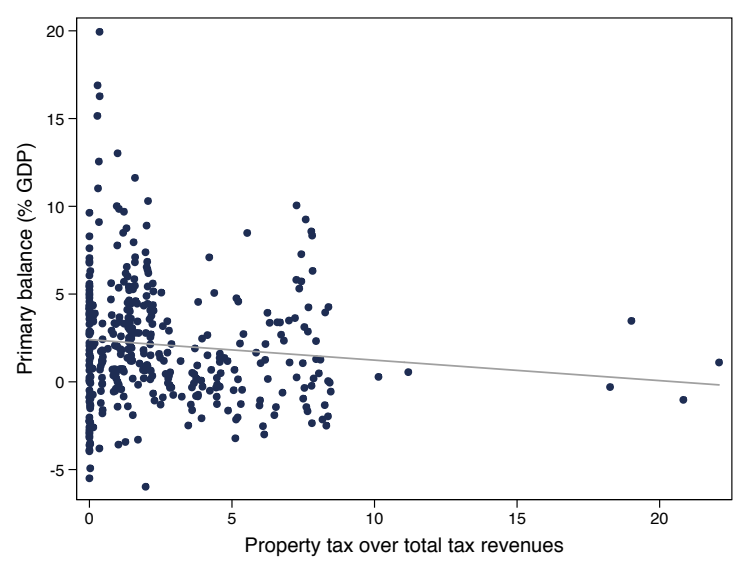

(b) Primary balance and property tax

Notes: elaborations on Government Finance Statistics (IMF).

tax revenue in $2006 .^{8}$

Finally, a preliminary bivariate pooled analysis of the relationship between property tax and primary balance suggests there is not any significant correlation. A simple scatter plot between the share of property tax over total tax revenue and primary balance (Figure 1, panel b) shows that the linear fit is virtually flat. In the following section we inspect more carefully this relationship in a multivariate setting.

\section{$3 \quad$ The empirical strategy}

\subsection{Models and variables}

To test whether the use of property taxation affects fiscal discipline in a country, we start our analysis by regressing the share of property taxes to general government tax revenues (PROPERTY/TOTAL) and a set of control variables (CONTROL) on the government primary balance-to-GDP ratio (PRIMARY BALANCE):

$$
\begin{aligned}
\text { PRIMARY BALANCE } & =\alpha_{1}+\beta_{1} \text { PROPERTY/TOTAL } L_{i t} \\
& +\sum_{j=1}^{n} \gamma_{1 j} \text { CONTROL } L_{j i t}+\lambda_{i}+\tau_{t}+\epsilon_{i t}
\end{aligned}
$$

\footnotetext{
${ }^{8}$ The standard deviation of the share of property tax in total tax revenue between countries is 1.3 times the one calculated within countries.
} 
where $i$ denotes the country, $t$ the year and $j$ the control variables. We measure the degree of fiscal discipline by primary rather than total balance - that is, we exclude interest payments on public debt - because primary expenditures are more easily under the control of governments and then are more representative of the country's fiscal discipline.

In the baseline specification, we control for a number of economic, socio-demographic and institutional variables typically considered as important determinants of fiscal outcomes. ${ }^{9} \mathrm{We}$ include two variables capturing the size of the country (measured by total population, POPULATION) and of the public sector (proxied by the ratio of government expenditures over GDP, GOVERNMENT SIZE). Larger governments, being a source of public sector inefficiencies, could be associated with larger deficits, while population may have a positive or negative influence on the country's fiscal stance according to whether economies or diseconomies of scale in provision of public goods prevail. We control for output growth (GDP GROWTH) and the unemployment rate (UNEMPLOYMENT), in order to capture possible influences of business cycle fluctuations on the fiscal stance, and for the logarithm of real GDP per capita (GDP PC) to capture possible asymmetric effects of the level of development on revenues and expenditures.

Since primary revenues and expenditures may be affected by the demographic structure of the country, we control for the share of non-working age population on total population $(D E$ PENDENCY RATIO). We take into account the effects of the institutional set-up on the fiscal stance including a binary variable taking value one for the presence of fiscal rules (BUDGET $B A L A N C E R U L E)$ and a synthetic measure of institutional quality capturing the extent of corruption, the quality of bureaucracy and the degree of impartiality and observance of law in the country (INSTITUTIONS). We expect that the stringency of rules-based fiscal governance and a higher quality of institutions should improve fiscal discipline (Von Hagen and Harden, 1995). Finally, the error term is composed by a country-specific time-invariant effects $\left(\lambda_{i}\right)$, a time-fixed effects $\left(\tau_{t}\right)$ and the idiosyncratic component $\left(\epsilon_{i t}\right)$. In this way we implicitly take into account important determinants of a country's fiscal stance that are persistent over time, like constitutional features (e.g., being federal or unitary country; having a presidential or parliamentary system; a proportional or plurality electoral rule).

To test the robustness of our results, we augment the baseline specification with additional control variables capturing other political, institutional and economic factors that may be correlated with the primary balance. In particular, we control for the political orientation of national governments (POLITICAL PARTY) and the degree of public sector's fragmen-

\footnotetext{
${ }^{9}$ See de Mello (2000), Thornton (2009), Neyapti (2010) and Baskaran (2012). Detailed information on definitions and sources of all the variables used in the analysis are reported in Table 1, together with summary statistics.
} 
tation in the country (FRAGMENTATION). The former is measured by a dummy variable taking value one for left-oriented national governments, traditionally considered more inclined to deficit spending. FRAGMENTATION is measured by the number of sub-national governments normalized on population density and takes into account possible negative coordination and lobbying effects on the primary balance. We consider two other macroeconomic variables that could drive fiscal policy: the presence of a banking crisis (BANKING CRISIS) and the difference between the actual and potential GDP (OUTPUT GAP), both calling for additional public spending and a worsening of the fiscal position. Finally, we control for possible effects of globalization and international integration, as measured by the sum of exports and imports over GDP (OPENNESS), on fiscal outcomes (Rodrik, 1998).

As property taxes are predominantly a local revenue item, the coefficient $\beta_{1}$ on PROPERTY/TOTAL may capture the possible laxness and discipline effects associated with revenue decentralization, other than the beneficial or adverse effects of levies on property. In order to wipe out the confounding effect of tax decentralization we estimate a second model in which we decompose the effect of PROPERTY/TOTAL in the weight of property taxes on local tax revenues (PROPERTY/LOCAL) and the share of local tax revenues on general government tax revenues $(L O C A L / T O T A L):{ }^{10}$

$$
\begin{aligned}
\text { PRIMARY BALANCE } & =\alpha_{2}+\beta_{2} \text { PROPERTY LOCAL } L_{i t} \\
& +\delta_{2} L O C A L / T O T A L_{i t} \\
& +\sum_{j=1}^{n} \gamma_{2 j} C_{\text {ONTROL }}+\lambda_{i}+\tau_{t}+\epsilon_{i t}
\end{aligned}
$$

where we refer to sub-national or local governments as all tiers of government differing from the central/federal one. ${ }^{11}$

\subsection{Estimation technique}

Models (1) and (2) are estimated by using an unbalanced panel of annual data for 19 OECD countries observed from 1985 until 2006. Both the starting date and the number of countries

\footnotetext{
${ }^{10}$ This definition of tax decentralization does not include local non-tax revenues and capital revenues, which are usually irregularly recorded. Likewise, grants from other government levels are excluded from the taxation concept. Further details on such variable are provided in Table 1.

${ }^{11}$ Even if countries considered in this study differ with respect to their legal and constitutional settings, all of them have at least two levels of government. The main differences consist in the meaning of 'local' governments in unitary and federal countries - e.g., in a Federal Union, 'state' also represents a 'sub-national' independent political institution - as well as in the number of hierarchical authorities - e.g., provinces, regions, cantons, municipalities, landers, autonomous communities, counties, and others. Data availability do not allow this horizontal disaggregation; then, for consistency, we consider the sum of local, state, provincial and other lower levels of government where available as the indicator of sub-national government activity.
} 
considered depend on data availability for institutional variables and fiscal rules. ${ }^{12}$

To estimate our baseline model we have to deal with two econometric issues. First, given the persistence of the dependent variable, the error term is likely to be serially correlated. Second, as many panel data sets encountered in macroeconomics and regional science, our dataset is likely to be characterized by cross-sectional or spatial dependence (Driscoll and Kraay, 1998).

A natural solution to auto-correlation in the error term is using the Newey and West (NW) corrected standard errors, which assume heteroskedasticity and autocorrelation up to some lags (Newey and West, 1987). However, NW standard errors are not robust to the presence of cross-sectional correlation (Hoechle, 2007). ${ }^{13}$ In fact, we test for cross-sectional dependence by performing the Pesaran (2004) CD test ${ }^{14}$ and we find that the test rejects the null hypothesis of spatial independence at any standard level of significance, confirming that the residuals are cross-sectionally correlated in our sample. Therefore, we estimate our baseline model using the fixed-effects estimator with the Driscoll and Kraay (DK) corrected standard errors, which are robust to heteroschedasticity, cross-sectional dependence and autocorrelation (Driscoll and Kraay, 1998). As benchmark, we use a three-lags correction for auto-correlated errors after observing the residuals correlation over time. However, results are robust to increasing the lag-structure up to four and six lags, when the correlation starts to become proximate to zero.

\section{Results}

In Tables 2 and 3 we report the results of the estimation of models (1) and (2), in which property taxes are measured as a share of, respectively, general government tax revenue and local tax revenue. In both tables we start by displaying the baseline specification. In subsequent columns we augment the baseline specification by including additional control variables one at a time, while the last column report results for the full model.

\subsection{Property tax and tax decentralization}

In Table 2, the coefficient on PROPERTY/TOTAL is statistically significant and positive across all the alternative specifications, lending support to the hypothesis that property taxation contributes to promote fiscal discipline. The economic effect is also meaningful: a one percent

\footnotetext{
${ }^{12}$ Specifically, the variable INSTITUTIONS can be computed starting from 1984 and only for 19 OECD countries, while BUDGET BALANCE RULE is collected from 1985. For robustness, however, we estimate models for more (23) countries and longer time period (1972-2006) excluding these variables.

${ }^{13}$ Assuming that the residuals of a panel model are correlated within but uncorrelated between groups of individuals often imposes an artificial and inappropriate constraint on empirical models. Assuming, instead, that the residuals are correlated both within groups as well as between groups would often be more natural.

${ }^{14}$ The Pesaran test is adequate for use with unbalanced panels, as in our case, according to the methodology implemented by De Hoyos and Sarafidis (2006). The results are not reported in the paper for the sake of brevity.
} 
increase in the share of property over total tax revenue is associated with around 0.2 percentage points improvement in the ratio of primary balance over GDP. To illustrate, according to the estimates reported in the first column, moving from a situation without property tax (as is the case for Sweden and Finland) to PROPERTY/TAXES $=1.5$, which corresponds to the sample median and approximately to the average value in the United Kingdom and Denmark, will translate into a 0.3 percentage points higher primary balance.

Our findings are consistent with the hypothesis that property taxes are less distortive and that, being visible and transparent, are likely to stimulate voters to be aware about the costs of public programs and politicians to be fiscally more disciplined (Oates, 2001). They are also consistent with previous studies highlighting the incentive effects of property taxes in controlling costs of the public sector (e.g., Glaeser, 1996; Borge and Rattso, 2008; Fiva and Ronning, 2008). Such beneficial effect of property taxation on fiscal outcomes finds correspondence in the empirical literature on fiscal decentralization in OECD countries, according to which not all taxes are the same for restrain public spending at the sub-national level, and only property taxes seem to favor smaller local governments (Liberati and Sacchi, 2013).

The estimation of equation (2) tries to identify whether the beneficial effect of property taxes on fiscal balance is due to a tax composition effect or to a more intense process of tax decentralization that comes with the use of local property taxes. This concern seems to be justified in our sample of developed countries. From the first column of Table 3 we can see that if we estimate a model controlling for the ratio of local tax revenues on general government tax revenues (LOCAL/TOTAL), there is a positive and significant correlation between the primary balance and the degree of tax decentralization, in line with the discipline effect of fiscal decentralization documented by Neyapti (2010) and Thornton (2009) for a sample of OECD countries. This effect is also economically meaningful, as the elasticity of the primary balanceto-GDP ratio with respect to our measure of tax decentralization is 0.45 .

However, when we control for the type of tax autonomy including jointly LOCAL/TOTAL and PROPERTY/LOCAL, we find that only the coefficient on the latter variable is statistically significant and positive across alternative specifications, while the one on tax decentralization becomes much smaller and no more significant at any conventional level. ${ }^{15}$ Even in this case, the effect of property taxes on fiscal balance can be considered economically significant, given

\footnotetext{
${ }^{15}$ Our results are by no means due to multicollinearity problems: PROPERTY/LOCAL and LOCAL/TOTAL are indeed correlated, but the coefficient is in absolute terms sufficiently small (0.27) to avoid any serious concern. The lack of statistical significance of the degree of fiscal decentralization can be explained by the fact that the aggregate $L O C A L$ TAXES includes all types of local tax revenue (i.e., more autonomous taxes, shared taxes, piggybacked taxes, fees, charges), making it difficult to disentangle a clear-cut effect of tax decentralization on fiscal discipline. Similar results of no-effect of tax decentralization on fiscal balances are found by Thornton (2009) for a sample of OECD countries for the period 1980-2000.
} 
that the elasticity of the primary balance-to-GDP ratio with respect to PROPERTY/LOCAL varies between 0.4 and 0.6. To have a better sense of the magnitude of such effect, we can observe that if the share of property taxes in local tax revenues increases from $0 \%(9.7 \%)$ to $31.5 \%$, the primary balance-to-GDP ratio increases by $1.9 \%(1.3 \%)$, all things equal. These changes correspond to Finland and Sweden (Italy) increasing their share of the property tax in local tax revenue to the average of the United States over the sample period.

Our findings imply that the relative advantage of property taxes with respect to other forms of local revenues (e.g., income taxes) in improving the primary balance is not conditional on the degree of tax decentralization. In this view, the key element to promote fiscal discipline is not the development of the decentralization process but the tax instrument at work. In particular, a greater autonomy in the administration of property taxes would incentivate a greater responsibility of the local policy-makers in both collection and spending activities, improving the nationwide fiscal position. Recent empirical studies on fiscal autonomy of lower tiers of governments (e.g., Oates, 2005; Weingast, 2009; Boetti et al., 2012) confirm this view and support the waves of reforms towards the devolution of taxing power to local governments insisting on property taxation instead of other forms of revenue or grants from upper-level governments.

\subsection{Control variables}

The coefficients on control variables have generally the expected signs and they are often statistically significant and stable across different model specifications. First, the negative coefficient on GOVERNMENT SIZE confirms that the size of the public sector is a source of inefficiency it being associated with a worse primary balance-to-GDP ratio (see also Neyapti, 2010). By contrast, the positive coefficient on POPULATION suggests that in larger countries the fiscal pressure could be reduced thanks to the exploitation of scale economies in the provision of public goods, leading to a better fiscal stance.

Second, the coefficients on the unemployment rate and GDP growth indicate that fiscal policy is counter-cyclical: the primary balance-to-GDP ratio improves when output growth accelerates and unemployment declines, while it makes worse in recessions (Baskaran, 2012).

The coefficient on the level of economic development $(G D P P C)$ is never statistically significant, even if its negative sign is somehow unexpected. As expected, instead, a higher dependency ratio is negatively associated with the primary balance, as it is likely to increase expenditures through social assistance and welfare spending programs.

The results on BUDGET BALANCE RULE and INSTITUTIONS indicate that the institutional framework matters for the fiscal balance. The presence of a budget balance rule is 
positively correlated with the primary balance-to-GDP ratio, even if it is hardly statistically significant. ${ }^{16}$ Our measure of institutional quality, instead, shows a positive and significant association with fiscal performance (Neyapti, 2010).

The effect of POLITICAL PARTY is not statistically significant, consistent with a not so obvious impact of the ideology of the ruling party on fiscal imbalances. While left-wing parties are likely to indulge in expansionary fiscal policies, some authors argue that they are also more likely to increase taxes, with no obvious effect on the level of public deficit and debt (Borrelli and Royed, 1995; Baskaran, 2010). By contrast, the coefficient on FRAGMENTATION is negative and statistically significant, suggesting that the presence of many hierarchical authorities is more susceptible to common pool problems, thus being more prone to worsen overall fiscal position of the country.

Finally, the coefficients on OUTPUT GAP and on BANKING CRISIS confirm the countercyclical pattern of fiscal policy, while the country's openness to trade is not statistically associated with the primary balance-to-GDP ratio.

\subsection{Robustness}

We test the robustness of our results on a larger sample and under different assumptions about the structure of the error term. The main results are reported in Table 4 . In the first three columns we report estimation results of our three main specifications (column 1 of Table 2 and columns 1-2 of Table 3) when we consider a larger sample of 23 countries over the period 1972-2006. ${ }^{17}$ Unfortunately, the increase in the sample size comes at the cost of dropping our measures of unemployment and institutional quality because of data unavailability. Even in this larger sample, we find evidence of a positive and robust correlation between the incidence of property taxation over total (and local) tax revenue and the primary balance-to-GDP ratio, irrespective of the degree of tax decentralization in the country.

The last six columns of Table 4 show that assuming a simplified structure of the error term, in which we do not model spatial correlation (columns 4-6) neither autocorrelation (columns 7-9), leads to a marginal increase of the standard errors but leaves the coefficients on our key variables statistically significant at the usual level of confidence.

\footnotetext{
${ }^{16}$ The limited statistical significance of BUDGET BALANCE RULE could reflect that rule implementation is weak, or that rules are introduced where fiscal performance is weaker in the first instance. In many countries, supranational budget balance rules applying to general governments have been implemented only in the half of 1990's and their impact on public finances may be not immediate, as a sufficient time lag is necessary to make it 'visible' and effective. Alternatively large standard errors may reflect measurement errors and the fact that the dummy variables can not adequately disentangle the effect of different rules. As observed by Debrun et al. (2008), numerical fiscal rules may differ with respect to their design: depending on their features or 'strength', rules could be more or less likely to have an impact on budgetary outcomes.

${ }^{17}$ The four countries added to the sample are Hungary, Japan, New Zealand and Poland.
} 
Finally, our results are robust to alternative specifications of the autocorrelation structure of the error term (i.e. four or more lags) and to the use of the Feasible Generalized Least Squares estimator. $^{18}$

\section{$5 \quad$ Summary and policy implications}

As recently put by The Economist (2013b), "ask an economist about which are the most efficient kinds of taxes, and property taxes will be high up on the list". In this paper, we focus on vices and virtues of property taxation for improving a country fiscal balance, by empirically assessing whether a larger incidence of property tax revenues over total tax revenues is associated with sounder or weaker fiscal positions. Our results, based on a sample of OECD countries over the period 1985-2006, show that the impact of a higher recourse to property taxation has a statistically and economically significant positive effect on the primary balance-to-GDP ratio. Moreover, we show that this effect is not entirely driven by the "decentralized" nature of property taxes, as the positive correlation between the incidence of property tax and the general government primary balance is independent of the degree of tax decentralization in the country. Instead, the positive effects of property taxes are likely to be due to their efficiency and incentive virtues and to the relative advantage of this form of taxation in promoting the accountability and discipline of local governments.

Recent institutional reforms have been aimed at strengthening fiscal governance and rules at the European Union level, as well as within single member states. These rules have been designed to promote nationwide fiscal sustainability and have important consequences for managing public finances in decentralized countries (Spilimbergo et al., 2009; Cottarelli and Schaechter, 2010; Hauptmeier et al., 2011). To this purpose, many scholars have suggested that "to ensure fiscal discipline, governments at all levels must be made to face financial consequences of their decisions" (Shah, 1998).

Therefore, in light of this statement one should ask in which way governments can be made fiscally responsible. The conventional wisdom based on both the First and the Second Generation theories of fiscal federalism (e.g., Weingast, 2009, 2014) suggests to confer fiscal autonomy to achieve the fiscal responsibility goal. Our results suggest that a major ingredient to ensure nationwide fiscal discipline is to rely on tax instruments with a certain intrinsic degree of autonomy, and they call for a further rethinking of fiscal policy in advanced economies. Actually, the limited effectiveness of the fiscal consolidation effort in several European countries is related to a deterioration in the budgetary situation of the various government levels - especially of

\footnotetext{
${ }^{18}$ These last results are not shown for brevity, but are available upon request.
} 
sub-national governments -, a decrease in revenue and, ultimately, to a lack of political will to strength fiscal governance and rules being able to favour the required budgetary adjustments. Among the tools that received a lot of resistance and proved themselves unpopular and politically unattractive, this paper show that property taxation is likely to make fiscal consolidation more effective. 


\section{REFERENCES}

Acosta-Ormaechea, S. and Yoo, J. (2012). Tax Composition and Growth: A Broad CrossCountry Perspective. IMF Working Paper 12/257, International Monetary Fund.

Arnold, J., Brys, B., Heady, C., Johansson, A., Schwellnus, C. and Vartia, L. (2011). Tax policy for economic recovery and growth. Economic Journal, 121, F59-F80.

BASKARAN, T. (2010). On the link between fiscal decentralization and public debt in OECD countries. Public Choice, 145, 351-378.

- (2012). Tax decentralization and public deficits in OECD countries. Publius: The Journal of Federalism, 42 (4), 688-707.

Blochliger, H. and Petzold, O. (2009). Finding the Dividing Line between Tax Sharing and Grants: A Statistical Investigation. Tech. rep., OECD Publishing.

Boetti, L., Piacenza, M. and Turati, G. (2012). Decentralization and local governments' performance: How does fiscal autonomy affect spending efficiency? Finanzarchiv-Public Finance Analysis, 68 (3), 269-302.

Borge, L.-E. and Rattso, J. (2008). Property taxation as incentive for cost control: Empirical evidence for utility services in Norway. European Economic Review, 52 (6), 1035-1054.

Borrelli, S. and Royed, T. (1995). Government strength and budget deficits in advanced democracies. European Journal of Political Research, 28 (2), 225-260.

Brennan, G. and Buchanan, J. M. (1980). The power to tax: Analytic foundations of a fiscal constitution. Cambridge University Press.

Cabral, M. and Hoxby, C. (2012). The Hated Property Tax: Salience, Tax Rates, and Tax Revolts. Tech. rep., National Bureau of Economic Research.

Cottarelli, C. and Schaechter, A. (2010). Long-Term Trends in Public Finances in the G-7 Economies. IMF Staff Position Note 10/13, International Monetary Fund, Washington D.C.

Crowley, G. R. and Sobel, R. S. (2011). Does fiscal decentralization constrain Leviathan? New evidence from local property tax competition. Public Choice, 149 (1-2), 5-30.

De Hoyos, R. E. and SARAfidis, V. (2006). Testing for cross-sectional dependence in panel data models. Stata Journal, 6, 482-496. 
DE Mello, L. (2000). Fiscal decentralization and intergovernmental fiscal relations: A crosscountry analysis. World Development, 28 (2), 365-380.

Debrun, X., Moulin, L., Turrini, A., Ayuso-i Casals, J. and Kumar, M. S. T. (2008). Tied to the mast? National fiscal rules in the European Union. Economic Policy, 23 (54), $297-362$.

Doerner, W. and Ihlanfeldt, K. (2011). House prices and city revenues. Regional Science and Urban Economics, 41 (4), 332-342.

Driscoll, J. C. and KraAy, A. C. (1998). Consistent covariance matrix estimation with spatially dependent panel data. Review of economics and statistics, 80 (4), 549-560.

Dziobek, C., Gutierrez Mangas, C. A. and Kufa, P. (2011). Measuring Fiscal Decentralization-Exploring the IMF's Databases. Tech. Rep. 11/126, IMF Working Papers, Washington D.C.

Fiva, J. H. and Ronning, M. (2008). The incentive effects of property taxation: Evidence from Norwegian school districts. Regional Science and Urban Economics, 38 (1), 49-62.

Glaeser, E. L. (1996). The incentive effects of property taxes on local governments. Public Choice, 89, 93-111.

Hauptmeier, S., Sanchez-Fuentes, A. J. and Schuknecht, L. (2011). Towards expenditure rules and fiscal sanity in the Euro area. Journal of Policy Modeling, 33 (4), 597-617.

Hoechle, D. (2007). Robust standard errors for panel regressions with cross-sectional dependence. The Stata Journal, 7, 281-312.

Holtz-Eakin, D. and Marples, D. (2001). Distortion Costs of Taxing Wealth Accumulation: Income Versus Estate Taxes. NBER Working Paper 8261, National Bureau of Economic Research.

Hoxby, C. M. (1999). The productivity of schools and other local public good producers. Journal of Public Economics, 74 (1), 1-30.

Joulfaian, D. (2006). The behavioural response of wealth accumulation to estate taxation: Time series evidence. National Tax Journal, 59, 253-268.

Kopczuk, W. (2010). Economics of Estate Taxation: NBER Working Paper 15741, National Bureau of Economic Research: A Brief review of Theory and Evidence. 
- and Slemrod, J. (2001). The impact of the estate tax on the wealth accumulation and avoidance behaviour of donors. In W. G. Gale, J. R. H. Jr and J. Slemrod (eds.), Rethinking Estate and Gift Taxation, Brookings Institution Press, pp. 299-343.

Laeven, L. and Valencia, F. (2012). Systemic Banking Crises Database: An Update. IMF Working Papers 12/163, International Monetary Fund.

Liberati, P. and SACChi, A. (2013). Tax decentralization and local government size. Public Choice, 157 (1), 183-205.

Lutz, B., Molloy, R. and Shan, H. (2011). The housing crisis and state and local government tax revenue: Five channels. Regional Science and Urban Economics, 41 (4), 306-319.

Martinez-VAzquez, J. (2008). Revenue assignments in the practice of fiscal decentralization. In Fiscal Federalism and Political Decentralization: Lessons from Spain, Germany and Canada, Edward Elgar Publishing, pp. 27-55.

Mauro, P., Romeu, R., Binder, A. and Zaman, A. (2013). A Modern History of Fiscal Prudence and Profligacy. IMF Working Papers 13/5, International Monetary Fund.

Newey, W. K. and West, K. D. (1987). A simple, positive semi-definite, heteroskedasticity and autocorrelation consistent covariance matrix. Econometrica, 55 (3), 703-708.

NeyApti, B. (2010). Fiscal decentralization and deficits: International evidence. European Journal of Political Economy, 26 (2), 155-166.

Norregatrd, M. J. (2013). Taxing Immovable Property Revenue Potential and Implementation Challenges. Tech. Rep. 13-129, International Monetary Fund.

OAtEs, W. (2005). Toward a second-generation theory of fiscal federalism. International Tax and Public Finance, 12, 349-373.

OAtes, W. E. (2001). Property taxation and local government finance. Lincoln Inst of Land Policy.

OECD (2012). Decentralisation and economic growth. Tech. rep., Organisation for Economic Co-operation and Development, Paris.

- (2013). Measuring Fiscal Decentralisation: Concepts and Policies. Tech. rep., OECD Fiscal Federalism Studies, OECD Publishing. 
Pesaran, M. H. (2004). General diagnostic tests for cross section dependence in panels. Tech. rep., University of Cambridge, Faculty of Economics, Cambridge Working Papers in Economics No. 0435 .

Rodriguez-Pose, A. and Gill, N. (2003). The global trend towards devolution and its implications. Environment and Planning C: Government and Policy, 21 (3), 333-351.

RoDRIK, D. (1998). Why do more open economies have bigger governments? Journal of Political Economy, 106 (5), 997-1032.

ShaH, A. (1998). Fiscal federalism and macroeconomic governance: for better or for worse? Tech. rep., The World Bank.

Spilimbergo, A., Symansky, S. A., Cottarelli, C. and Blanchard, O. J. (2009). Fiscal Policy for the Crisis. Tech. rep., International Monetary Fund.

Teorell, J., Charron, N., Samanni, M., Holmberg, S. and Rothstein, B. (2011). The Quality of Government Dataset. Tech. rep., University of Gothenburg: The Quality of Government Institute.

TeR-Minassian, T. (1997). Intergovernmental fiscal relations in a macroeconomic perspective: an overview. In T. Ter-Minassian (ed.), Fiscal federalism in theory and practice, Washington: International Monetary Fund, pp. 3-24.

The Economist (2013a). Levying the land. The Governments should make more use of property taxes, Print edition, June 29th.

The Economist (2013b). Property taxes: An unexploited resource, Blog edition, June 27th.

Thornton, J. (2009). The (non) impact of revenue decentralization on fiscal deficits: some evidence from oecd countries. Applied Economics Letters, 16 (14), 1461-1466.

Von Hagen, J. and HARDEn, I. J. (1995). Budget processes and commitment to fiscal discipline. European Economic Review, 39 (3-4), 771-779.

Weingast, B. R. (2009). Second Generation Fiscal Federalism: The Implications of Fiscal Incentives. Journal of Urban Economics, 65 (3), 279-293.

- (2014). Second Generation Fiscal Federalism: Political Aspects of Decentralization and Economic Development. World Development, 53, 14-25.

WibBels, E. (2000). Federalism and the politics of macroeconomic policy and performance. American Journal of Political Science, pp. 687-702. 
Tables 


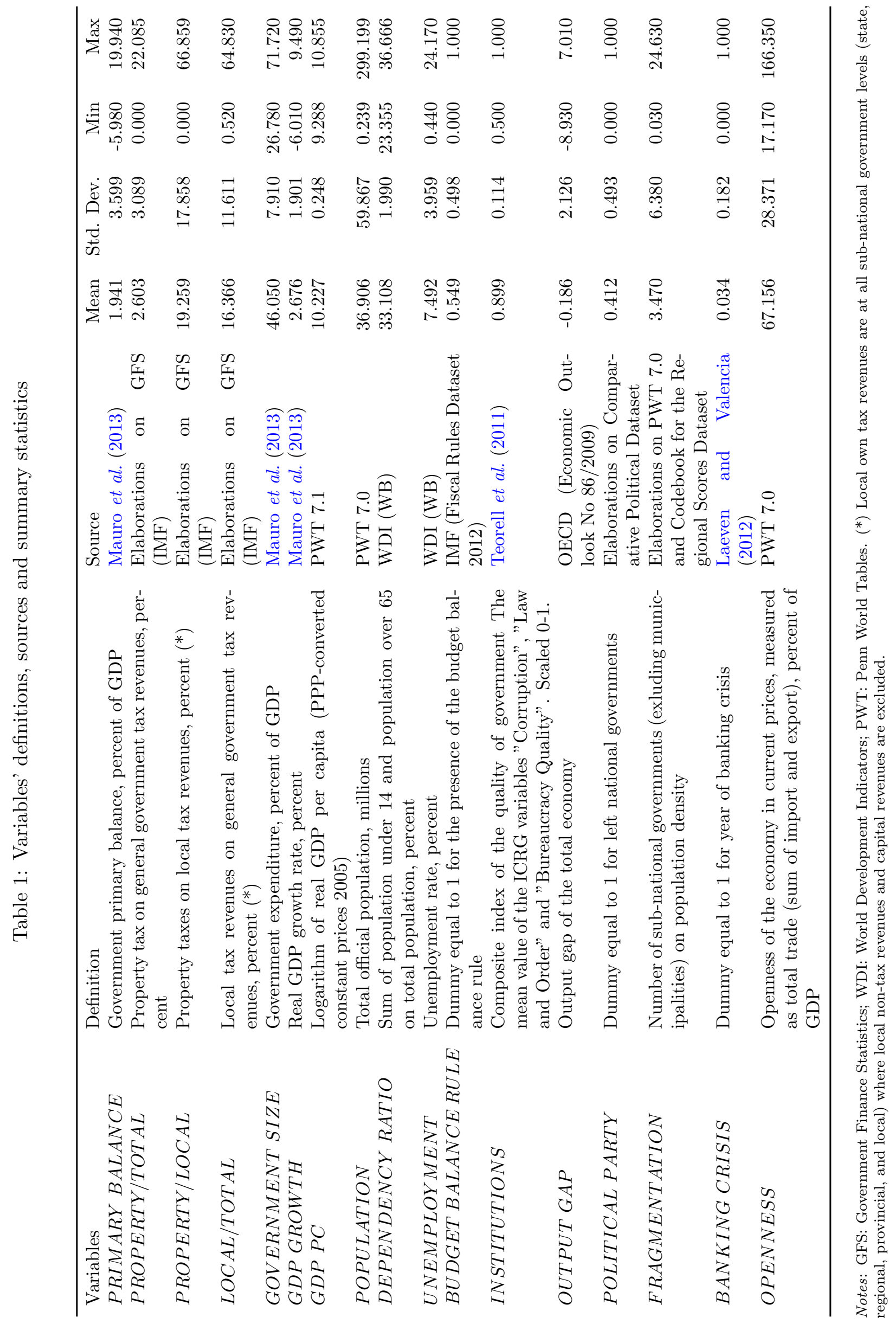




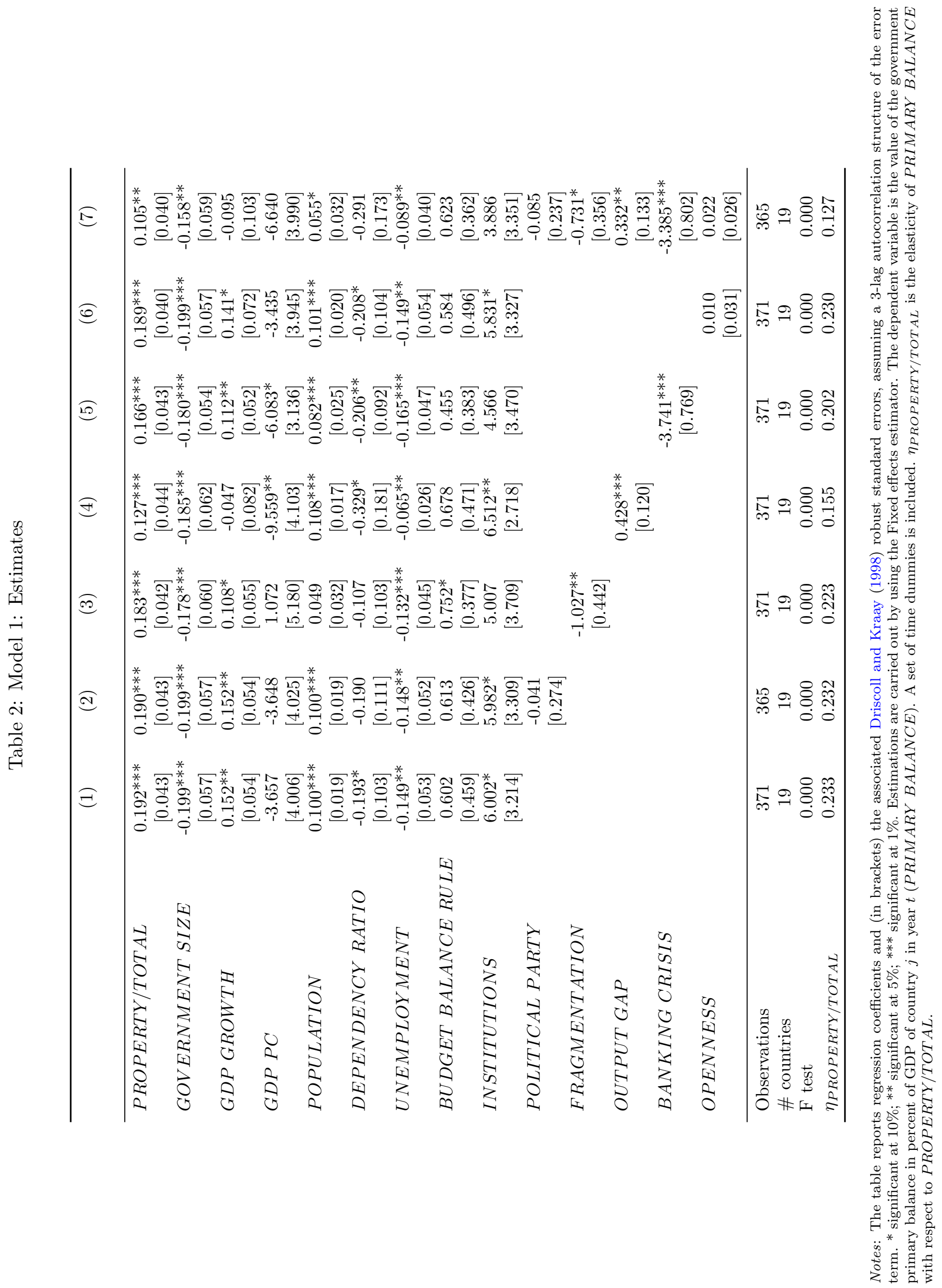




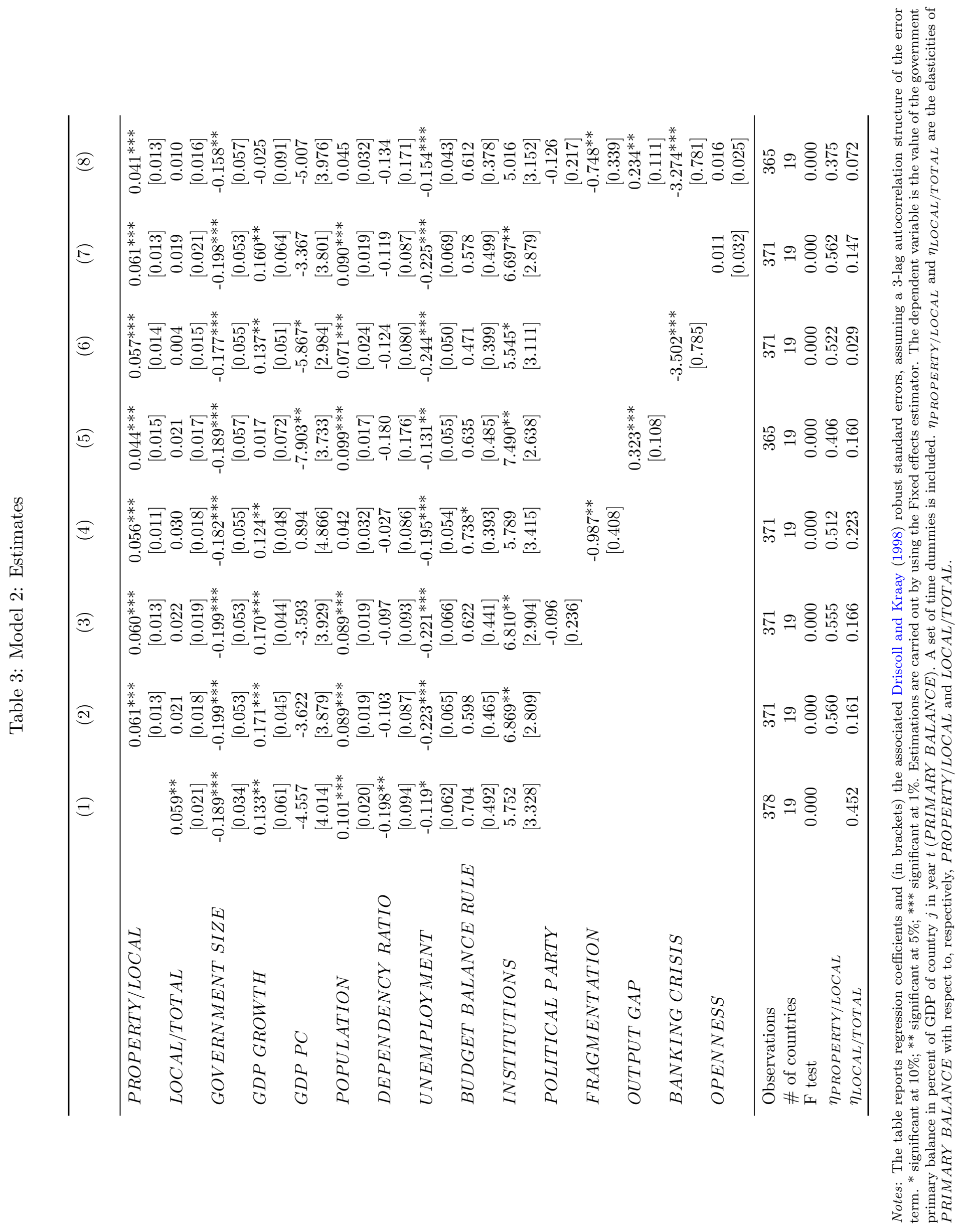




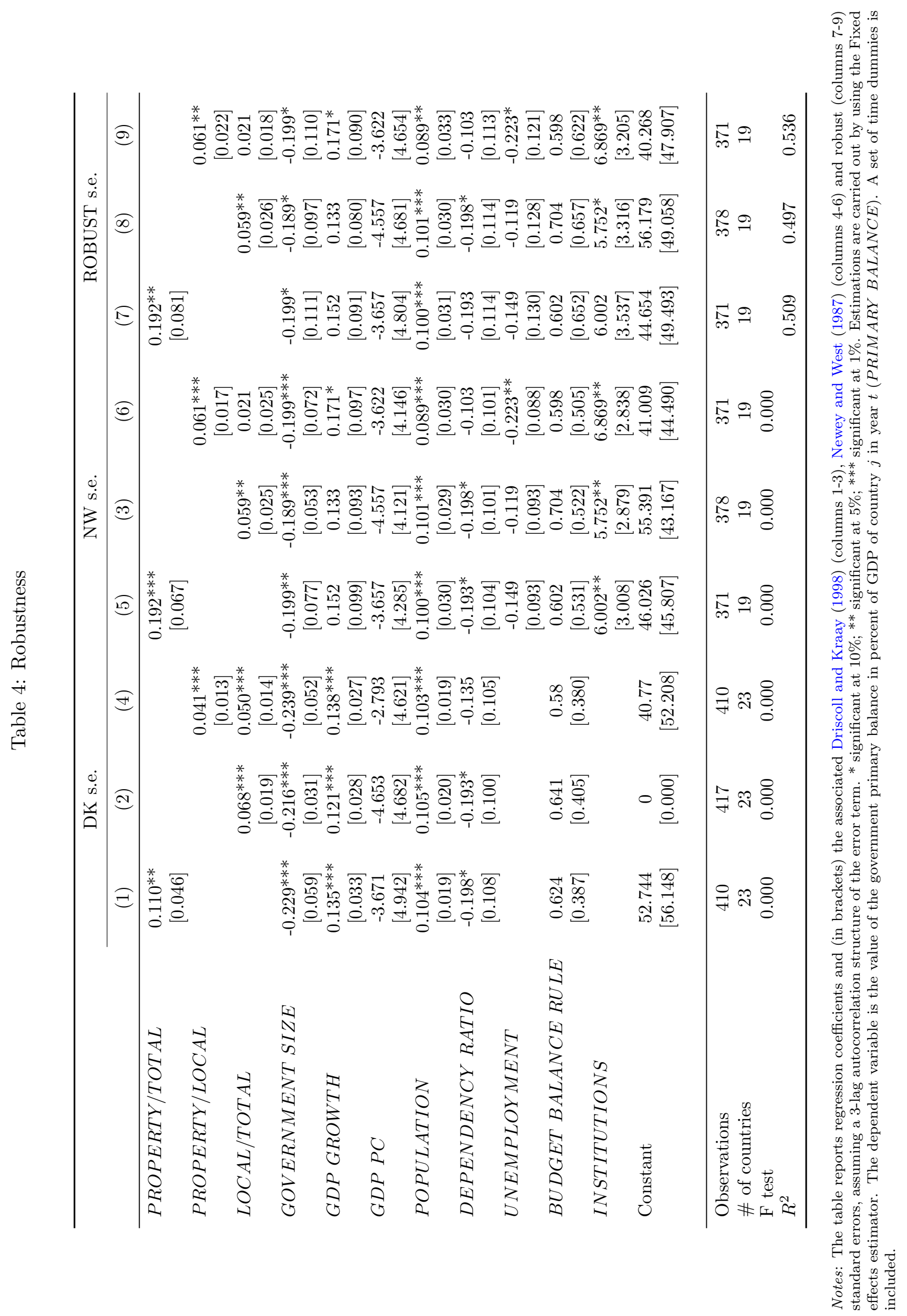

